\title{
Leaves and seeds of Syzygium cumini extracts produce significant attenuation of 2,2 azobis-2-amidinopropane dihydrochloride-induced toxicity via modulation of ectoenzymes and antioxidant activities
}

\author{
Raphaela M. Borges ${ }^{1}$, Paula E. R. Bitencourt ${ }^{1}$, Carolina S. Stein ${ }^{1}$, Guilherme V. Bochi ${ }^{3}$, Aline Boligon ${ }^{2}$, \\ Rafael Noal Moresco ${ }^{1}$, Maria Beatriz Moretto ${ }^{1 *}$ \\ ${ }^{1}$ Departamento de Análises Clínicas e Toxicológicas, Centro de Ciências da Saúde, Programa de Pós-Graduação em Ciências Farmacêuticas, Universidade \\ Federal de Santa Maria, Santa Maria, RS, Brazil. ${ }^{2}$ Departamento de Farmácia Industrial, Centro de Ciências da Saúde, Programa de Pós-Graduação em \\ Ciências Farmacêuticas, Universidade Federal de Santa Maria, Santa Maria, Brazil. ${ }^{3}$ Departamento de Farmacologia, Centro de Ciências da Saúde, \\ Programa de Pós-Graduação em Farmacologia, Universidade Federal de Santa Maria, Santa Maria, RS, Brazil.
}

\section{ARTICLE INFO}

Article history:

Received on: $15 / 12 / 2016$

Accepted on: 24/02/2017

Available online: $30 / 06 / 2017$

\section{Key words:}

NTPDAses activities; inflammation; cytotoxicity; AAPH-induced oxidative damage; lymphocytes; medicinal plant.

\begin{abstract}
Syzygium cumini has shown many pharmacologic properties including anti-inflammatory. Here, we analyzed the antioxidant activity of leaves and seeds from aqueous extracts of S. cumini (LASc, SASc, respectively) as well as their effect in a 2,2 azobis-2-amidinopropane dihydrochloride (AAPH) induced model of oxidative damage in human lymphocytes, in vitro. It was evaluated the ferric reducing power (FRAP), scavenging of 1,1-diphenyl-2picrylhydrazyl (DPPH), nitric oxide, hydrogen peroxide radicals and thiol peroxidase-like activity from both extracts. Lymphocytes obtained from blood samples of healthy volunteers were incubated with LASc and SASc $(50,100$ and $500 \mu \mathrm{g} / \mathrm{mL})$ and gallic acid $(\mathrm{GA})(100 \mu \mathrm{M})$ followed or not by incubation with AAPH $(1 \mathrm{mM})$. Afterwards, enzymatic activities, oxidative parameters and cytotoxicity were evaluated. This study indicates that extracts of S.cumini (i) exhibiting antioxidant activity; (ii) prevented the increase of ectonucleotidase and adenosine deaminase (ADA) activities; (iii) prevented inhibition of acetylcholinesterase (AChE) activity; (iv) protected P-SH groups, decreased lipoperoxidation and NO production; (v) improved the cellular viability in AAPH-induced model of lymphocytes. S. cumini extracts modulate ectonucleotidase, ADA, AChE activities maintaining levels normal of ATP, adenosine (Ado) and acetylcholine (ACh) and markedly attenuate inflammatory process. In conclusion, S.cumini has protective and immunomodulatory effects on AAPH-induced damage in lymphocytes, in vitro.
\end{abstract}

\section{INTRODUCTION}

Natural products have been accepted as an important tool to obtain bioactive compounds with therapeutically effective medicines in the prevention and/or treatment of a number of diseases, but the mechanisms involved in it have not been completely understood yet. Syzygium cumini (L.) Skeels from Myrtaceae family is a worldwide medicinal popular plant, commonly known as jambolan or jamun, possesses a wide range of medicinal properties such as anti-inflammatory, antioxidant, hypoglycemic and anti-microbial activities, as well as hepatoprotective and cardioprotective effects which have been

* Corresponding Author

E-mail: beatriz@smail.ufsm.br attributed to the presence of bioactive molecules in different parts of the plant (Ayyanar and Subash-Babu, 2013; Cargnelutti et al., 2015). In Brazil, the leaves and seeds are the parts of the plant most used by the population in folk medicine (Vizzoto and Pereira, 2008).

The $S$. cumini's leaves and seeds have been reported to be rich in phenolic compounds, which contribute for the scavenging of free radicals with significant antioxidant activity and protective effect on antioxidant enzymes (Ravi et al., 2004a; Ravi et al., 2004b; Bajpai et al., 2005). Among this class of compounds, gallic acid stands out, a phenolic acid, widely present in extracts from different parts of S. cumini (De Bona et al., 2011; Cargnelutti et al, 2015) which have already reported antioxidant, anti-inflammatory and antimicrobial activities (Kim et al., 2006; Padma et al., 2011; Borges et al., 2013). 
Oxidative stress is characterized by the imbalance between oxidants and antioxidants in favor of the oxidants which are formed as a result of normal cellular aerobic metabolism but during pathophysiological conditions can be produced at an elevated rate (Roberts et al., 2010). Accumulating evidence suggests that high levels of ROS may cause oxidative changes to DNA, protein and lipids and additionally are involved in several diseases pathogenesis of, including changes in the immune system (Brigelius-Flohe and Flohe, 2011; Ray et al., 2012). The immune system changes are critical for its normal functioning, mainly for lymphocytes, the most important cells involved in this system (Delves et al., 2006). In general, exposure to high levels of free radicals has a negative impact on this system and is linked to a loss of T-cell homeostasis and antioxidant defense, lymphocytes activation, cell damage and limited viability (Cope, 2002; Perez de Castro et al., 2004). The inflammatory process involves activation of the immune system and interaction between several components (Rock et al., 2005), including molecules of a purinergic and cholinergic system that contribute to their responses (Bours et al., 2006; Kawashima and Fujii, 2003). Thus, one of the ways in which lymphocyte function may be regulated is by a member of the ectonucleoside triphosphate phosphohydrolase (E-NTPDase) family characterized as marker of lymphocyte activation, the NTPDase (EC 3.6.2.5, CD39). The NTPDase is an ectoenzyme that hydrolyzes extracellular nucleotide (preferably ATP and ADP) (Leal et al., 2005) and the sequential hydrolysis of nucleotide generates ADP, AMP, and adenosine (Ado) that are involved in the regulation of immune defenses (Burch, 2006). The extracellular ATP acts as a pro-inflammatory molecule and stimulates the release of pro-inflammatory cytokines from activated lymphocytes (Langston et al., 2003).

Conversely, the breakdown product of ATP, the Ado, exhibits potent anti-inflammatory activity and has the ability to alter the lymphocyte activation and cytokine production (Gessi et $a l$. , 2007). The adenosine levels are regulated by the adenosine deaminase activity (ADA, E.C 3.5.4.4) an enzyme from the purine metabolism that catalyzes the deamination of Ado and deoxyadenosine into inosine and deoxyinosine, respectively (Spychala, 2000). Two ADA's different isoenzymes designated as ADA1 and ADA2 have been reported in mammals. ADA1 isoenzyme is found in higher activity in lymphocytes and monocytes, whereas ADA2 is the predominant isoenzyme in the serum (Ungerer et al., 1992). In fact, in the inflammatory process ADA activity is increased (Schetinger et al., 2007). Also, in this context, nitric oxide (NO), in addition to being a highly reactive radical is also a pro-inflammatory mediator that contributes to the development of a variety of inflammatory diseases (Kim et al., 2010). In addition, another important enzyme in the immune regulation is the acetylcholinesterase (AChE). The lymphocytes possess a complete cholinergic system consisting of acetylcholine (ACh), muscarinic and nicotinic receptors, choline acetyltransferase, and AChE (EC 3.1.1.7). This enzyme is a hydrolase that catalyzes the rapid hydrolysis of ACh (Gabrovska et al., 2008) that is the main circulating molecule involved in cholinergic functions that may regulate several physiological functions, including immune modulation (Tayebati et al., 2002).

In previous studies of our group we observed that leaves extracts from $S$. cumini protect the lymphocytes against in vitro oxidative stress (De Bona et al., 2015) and different parts of $S$. cumini demonstrated beneficial effects against diabetes mellitus in vitro and in vivo (De Bona et al., 2014; Bitencourt et al., 2015). Therefore, aqueous seeds and leaves extracts of $S$. cumini are potential candidates to analyze its effects. As a result of the importance of this plant in traditional Brazilian medicine and in order to extend these observations to further investigate its antioxidant properties using 2,2 azobis-2-amidinopropane dihydrochloride (AAPH), a water-soluble azo compound that is thermally decomposed to generate peroxyl radicals at a constant rate, this study was carried out to evaluate the antioxidant activity as well as the effects of LASc and SASc on the cytotoxicity and enzymatic activities on AAPH exposure in human lymphocytes by scientifically validated in vitro techniques.

\section{MATERIALS AND METHODS}

\section{Chemicals}

2,2-diphenyl-1- picrylhydrazyl (DPPH), Acetylthiocholine iodide,5'5 dithio-bis-2-nitrobenzoic acid (DTNB), 2,2azobis-2-amidinopropane dihydrochloride (AAPH) 3[4,5-dimethylthiazol-2-yl]-2,5-diphenyl tetrazolium bromide (MTT), the substrates ATP, ADP and adenosine, Gallic acid and Ficoll-Histopaque ${ }^{\mathrm{TM}}$ plus were obtained from Sigma Chemical Co (St. Louis, MO). All other reagents used in the experiments were of analytical grade and highest purity.

\section{Plant material and aqueous extracts of $S$. cumini preparation}

$S$. cumini seeds and leaves were collected $\left(29^{\circ} 43^{\prime} 22^{\prime \prime S}\right.$ and $53^{\circ} 43^{\prime} 47^{\prime \prime} \mathrm{W}$ ) in Santa Maria, Rio Grande do Sul, Brazil) and identified by the Laboratory of Botanic and Pharmacognosy of the Federal University of Santa Maria (voucher number SMDB 14.001). For the preparation of the aqueous seeds extract (SASc), eighty grams of the seed powder were extracted with $400 \mathrm{~mL}$ of distilled water during $1 \mathrm{~h}$ under reflux (Prince et al., 1998). For the preparation of the aqueous leaves extract (LASc), they were dried in a greenhouse with air circulation at $40{ }^{\circ} \mathrm{C}$ for approximately 48h. Then, they were ground in a knife mill and submitted to extraction until exhaustion (Eidi et al., 2006). The presence of 11 antioxidant compounds in both extracts, namely gallic, caffeic and ellagic acids, chlorogenic, catechin, quercetin, epicatechin, quercitrin, isoquercitrin, kaempferol and rutin was investigated by high-performance liquid chromatography with diode array detector (HPLC-DAD). The chemical characterization of the extracts was determined in recent studies as described in Bitencourt et al. (2016) and Cargnelutti et al. (2015). The HPLC fingerprinting of both extracts revealed that the gallic acid (GA) is the major component of the extracts. Then, the antioxidant activities of the LASc and SASc were compared with the antioxidant activity of GA used as a positive standard in the in vitro tests. 
Antioxidant activities of extracts

Free radical scavenging ability by the use of a stable DPPH radical

DPPH free radical scavenging activity was determined by reported earlier (Joshi et al., 2011). LASc, SASc and GA at the concentrations of $25,50,100,200,400$ and $800 \mu \mathrm{g} / \mathrm{mL}$, were added to an ethanolic DPPH solution $(6 \mathrm{mM})$. The mixture was incubated at room temperature for $30 \mathrm{~min}$ and determined the absorbance at $518 \mathrm{~nm}$. The percent inhibition was calculated. The dark color of the DPPH radical solution becomes lighter when it is incubated with an antioxidant and the decrease in color indicated the scavenger potential of the antioxidant compounds in relation to ability to donate a hydrogen or electron.

\section{Ferric reducing antioxidant power (FRAP) assay}

The FRAP assay was used to measure the reducing antioxidant power of LASc, SASc and GA at the concentrations 25, 50, 100, 200, 400 e $800 \mu \mathrm{g} / \mathrm{mL}$ (Benzie and Strain, 1996). The results were presented as $\mu \mathrm{M} \mathrm{Fe} e^{2+} / \mathrm{mL}$ of extract.

\section{Thiol Peroxidase-Like Activity of Extracts}

The catalytic effect of LASc, SASc and GA on the reduction of hydrogen peroxide $\left(\mathrm{H}_{2} \mathrm{O}_{2}\right)$ by reduced glutathione (GSH) was assessed using the rate of GSH oxidation. Different concentrations of extracts were incubated in the medium containing GSH (1mM) with and without $\mathrm{H}_{2} \mathrm{O}_{2}(0.3 \mathrm{mM})$. At 120 min, aliquots of the reaction mixture $(200 \mu \mathrm{L})$ were checked for the amount SH groups according to Ellman (1959) and the values were expressed in percentage of control (Souza et al., 2009).

\section{Nitric Oxide-Scavenging Assay}

The scavenging effect of aqueous extracts on nitric oxide (NO) was measured according to the method of Sreejayan and Rao (1997). For the assay, sodium nitroprusside (10mM), was mixed with LASc, SASc and GA (50, 100, 200, 400 and 800 $\mathrm{g} / \mathrm{mL})$, incubated for $150 \mathrm{~min}$ and then mixed with $0.5 \mathrm{~mL}$ of Griess reagent and measured at $546 \mathrm{~nm}$. In the control, sample extract was substituted by PBS. The capability of scavenging NO was calculated using the following equation: Scavenging effect $(\%)=$ $[1-($ A sample/A control) $] \times 100$.

\section{Hydrogen peroxide-Scavenging Assay}

The ability of the extracts and GA to scavenge hydrogen peroxide was determined according to the method of Ruch et al. (1989). LASc, SASc $(5,10,25,50$ and $100 \mu \mathrm{g} / \mathrm{mL})$ were added to a hydrogen peroxide solution $(0.6 \mathrm{~mL}, 40 \mathrm{mM})$. The absorbance of hydrogen peroxide at $230 \mathrm{~nm}$ was determined 10 minutes later against a blank solution containing the phosphate buffer without hydrogen peroxide. The percentage of hydrogen peroxide scavenging of the extracts were calculated: \% Scavenged $\left[\mathrm{H}_{2} \mathrm{O}_{2}\right]=$ $\left[\left(\mathrm{A}_{0}-\mathrm{A}_{1}\right) / \mathrm{A}_{0}\right] \times 100$, where $\mathrm{A}_{0}$ was the control absorbance and $A_{1}$ the absorbance in the presence of extract or standard.

\section{Sample collection and isolation of lymphocytes from human blood}

Lymphocytes were isolated from blood taken from healthy volunteers, after informed consent was obtained, and collected in Vacutainer tubes (BD Vacutainer, Franklin Lakes, NJ) containing lithium-heparin or EDTA (only NTPDase activity) as anticoagulant and separated on Ficoll-HistopaqueTM plus density gradients, according to the technique described by Böyum (1968). Cell number and viability were determined by Trypan blue exclusion. More than $95 \%$ of the cells were found to be viable. The final cell suspensions were performed in phosphate-buffered saline (PBS, pH 7.4) or in saline solution (for NTPDase activity) and $3 \times 106$ cells $/ \mathrm{mL}$ were used for each analysis. All experiments were performed at least three times using lymphocytes obtained at different occasions and a total of eight samples were used for every incubation performed. The study was approved by the Ethics Committee of the Federal University of Santa Maria (experimental protocol 54224316.1.0000.5346.).

\section{In vitro experimental design}

Primarily, lymphocytes suspensions were preincubated with different concentrations of LASc, SASc (50, 100 and 500 $\mu \mathrm{g} / \mathrm{mL})$ and $\mathrm{GA}(100 \mu \mathrm{M})$ at $37{ }^{\circ} \mathrm{C}$ for $30 \mathrm{~min}$, followed by incubation in oxidative stress condition with AAPH $(1 \mathrm{mM})$ at $37^{\circ} \mathrm{C}$ for $2 \mathrm{~h}$. Also, were observed the per se effect of LASc, SASc and GA. The choice of the concentrations of the extracts and GA for the experiments was made based on the development of a concentration curve (data not shown) and also earlier studies (De Bona et al., 2015). All the procedures for enzymatic assays, oxidative stress parameters and viability assays were the same as described below.

\section{Enzymatic assays in lymphocytes suspensions NTPDase activity}

After obtaining of lymphocytes suspension, NTPDase activity was determined according to the method of Leal et al. (2005). Protein content of all samples were adjusted to 0.1-0.2 $\mathrm{mg} / \mathrm{mL}$ and $20 \mu \mathrm{L}$ of intact cells suspended in saline solution were added to a reaction medium containing $5 \mathrm{mM} \mathrm{CaCl}_{2}, 120 \mathrm{mM}$ $\mathrm{NaCl}, 5 \mathrm{mM} \mathrm{KCl}, 60 \mathrm{mM}$ glucose, and $50 \mathrm{mM}$ Tris- $\mathrm{HCl}$ buffer, $\mathrm{pH} 8.0$ at a final volume of $200 \mu \mathrm{L}$ and preincubated for $10 \mathrm{~min}$ at $37^{\circ} \mathrm{C}$. The reaction was started by the addition of ATP or ADP substrate at a final concentration of $2 \mathrm{mM}$ and incubation proceeded for $70 \mathrm{~min}$. After the incubation time, $200 \mu \mathrm{L}$ of $10 \%$ trichloroacetic acid (TCA) was added to the medium to stop the reaction.

The samples were chilled on ice for $10 \mathrm{~min}$ before testing for the release of inorganic phosphate $(\mathrm{Pi})$ as described by Chan et al. (1986) using malachite green as colorimetric reagent and $\mathrm{KH}_{2} \mathrm{PO}_{4}$ as standard. Controls with the addition of the enzyme preparation (intact lymphocytes) after the addition of TCA were used to correct for non-enzymatic hydrolysis of the substrate. The results were expressed as nmol $\mathrm{Pi}$ released/min/mg of protein. 


\section{ADA activity}

ADA activity in lymphocytes suspension was estimated spectrophotometrically using the method as described by Giusti and Gakis (1984) which is based on the direct measurement of the formation of ammonia produced when ADA acts in excess of adenosine. The activities of total ADA in the presence and absence of erythro-9-(2-hydroxy-3-nonyl) adenine (EHNA) were measured. Lymphocytes were treated with $100 \mu \mathrm{M}$ EHNA, a potent ADA1 inhibitor. ADA1 activities were calculated by subtracting the activity of ADA2 from that of total ADA. The protein content used for the assay was adjusted to between 0.7 and $0.9 \mathrm{mg} / \mathrm{mL}$. The results were expressed as units per liter (U/L).

\section{AChE activity}

AChE activity in lymphocytes was performed by the colorimetric method described by Ellman et al. (1961). Two hundred microliters of intact cells was added to a reaction mixture composed of $1 \mathrm{mM}$ acetylthiocholine (AcSCh), $0.1 \mathrm{mM} \mathrm{5,5'-}$ dithio-bis-2-nitrobenzoic acid (DTNB), and 0.1 M phosphate buffer ( $\mathrm{pH}$ 8.0). Immediately, the absorbance was read on a spectrophotometer at $412 \mathrm{~nm}$, before and after incubation for 30 $\mathrm{min}$ at $27^{\circ} \mathrm{C}$. The results are expressed as $\mu \mathrm{mol} \mathrm{AcSCh} / \mathrm{h} / \mathrm{mg}$ of protein. Physostigmine, a classic inhibitor, in the concentration of $100 \mu \mathrm{g} / \mathrm{mL}$ was used as a positive control of inhibition enzymatic activity (Hassan et al., 2013).

\section{Oxidative stress parameters}

\section{Thiobarbituric acid reactive substances (TBARS)}

Lipoperoxidation was estimated in lymphocytes by measurement of TBARS according to the method of Ohkawa et al. (1979). Lymphocytes were mixed with $8 \%$ SDS solution and incubated for $5 \mathrm{~min}$ at room temperature. Glacial acetic acid (20\%) was added to the reaction mixture and incubated for 2-5 min at room temperature. Finally, $0.8 \%$ TBA solution was added to the reaction mixture followed by incubation for $1 \mathrm{~h}$ in a boiling water bath. The reaction mixture was cooled, centrifuged and the absorbance of the supernatant was measured spectrophotometrically at $532 \mathrm{~nm}$. The results were expressed in $\mathrm{nmol}$ $\mathrm{MDA} / \mathrm{mL}$.

\section{Protein thiol (P-SH) groups}

$\mathrm{P}-\mathrm{SH}$ groups in lymphocyte suspensions were determined by the method of Boyne and Ellman (1972), modified by JacquesSilva et al. (2001), which consisted of the reduction of DTNB in $0.3 \mathrm{M}$ phosphate buffer $(\mathrm{pH} 7.0)$ measured at $37^{\circ} \mathrm{C}$ and at $412 \mathrm{~nm}$. A standard curve using glutathione was constructed in order to calculate P-SH group. The results were expressed as nmol P$\mathrm{SH} / \mathrm{mg}$ protein.

\section{Oxide nitric (NO) measurement}

NO was determined indirectly by quantifying in lymphocytes. NO was measured by the modified Griess method using the Cobas Mira ${ }^{\mathrm{TM}}$ automated analyzer as described by Tatsch et al. (2011). The results were expressed as $\mu \mathrm{M} / \mathrm{L}$.

\section{Cell viability \\ Tetrazolium salt method (MTT)}

The viability assay was performed by the colorimetric MTT method. 1.2 mM of MTT was added to the cell suspension following by incubation at $25{ }^{\circ} \mathrm{C}$ for $60 \mathrm{~min}$. The formazan product obtained during the incubation was solubilized in dimethyl sulfoxide (DMSO) and quantified by spectrophotometer at $560 \mathrm{~nm}$ (Moretto et al., 2007). Only viable cells are able to reduce MTT, therefore, each value obtained is proportional to the percentage of cell viability in relation to control considered as $100 \%$ of viability.

\section{Protein determination}

Protein concentration was measured according to the method of Lowry et al. (1951) using serum albumin as standard.

\section{Statistical Analysis}

The analyses were performed using STATISTICA for Windows, version 6.0 (StatSoft. Inc., Tulsa, OK, USA). All data were analyzed using one-way ANOVA, followed by Duncan's multiple range test. All data were expressed as mean \pm standard error of the mean (SEM). A value of $\mathrm{p}<0.05$ was considered statistically significant for all analyses.

\section{RESULTS}

\section{Antioxidant activities of extracts DPPH}

Radical scavenging activity of S. cumini extracts and GA against stable $\mathrm{DPPH}^{*}$ (2,2-diphenyl-2-picrylhydrazyl hydrate) demonstrated high radical scavenging activity $(\mathrm{p}<0.001)$ and LASc $(400 \mu \mathrm{g} / \mathrm{mL})$ had a greater effect than SASc (Fig. 1a).

\section{Hydrogen peroxide-Scavenging Assay}

The free radical scavenging activity of LASc, SASc and GA was also examined by using hydrogen peroxide free radical (Fig. 1b). LASc, at lower concentrations (5 and $10 \mu \mathrm{g} / \mathrm{mL}$ ), exhibited greater $\mathrm{H}_{2} \mathrm{O}_{2}$ scavenging activity than SASc. But, this scavenging ability became similar at high concentrations $(25,50$ and $100 \mu \mathrm{g} / \mathrm{mL})$. Even, at the elevated concentration tested (100 $\mu \mathrm{g} / \mathrm{mL}$ ), the LASc and SASc scavenging capacity presented equally to GA.

\section{FRAP}

The GA and the extracts' reducing ability to convert ferric ions to ferrous showed that LASc and SASc at 25, 50, 100 and $200 \mu \mathrm{g} / \mathrm{mL}$ had a similar reduction power in the FRAP assay (Fig. 1c) and LASc $(400 \mu \mathrm{g} / \mathrm{mL})$ presented higher reducing power than SASc $(\mathrm{p}<0.001)$. 

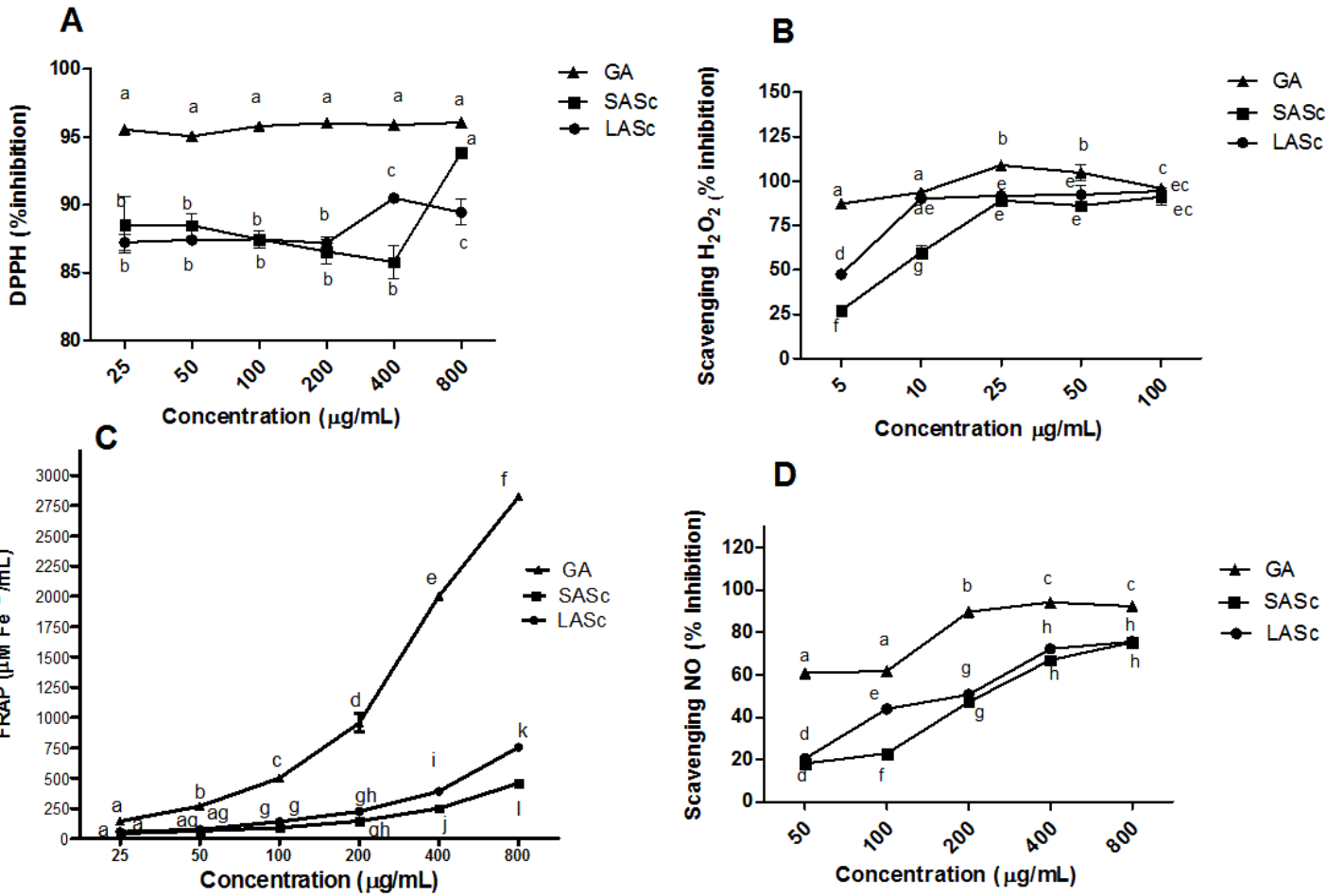

Fig. 1: Antioxidant activities of LASc, SASc and GA.

(a) DPPH assay (b) Hydrogen peroxide-Scavenging activity, (c) Ferric reducing antioxidant power, (d) NO scavenging.

A

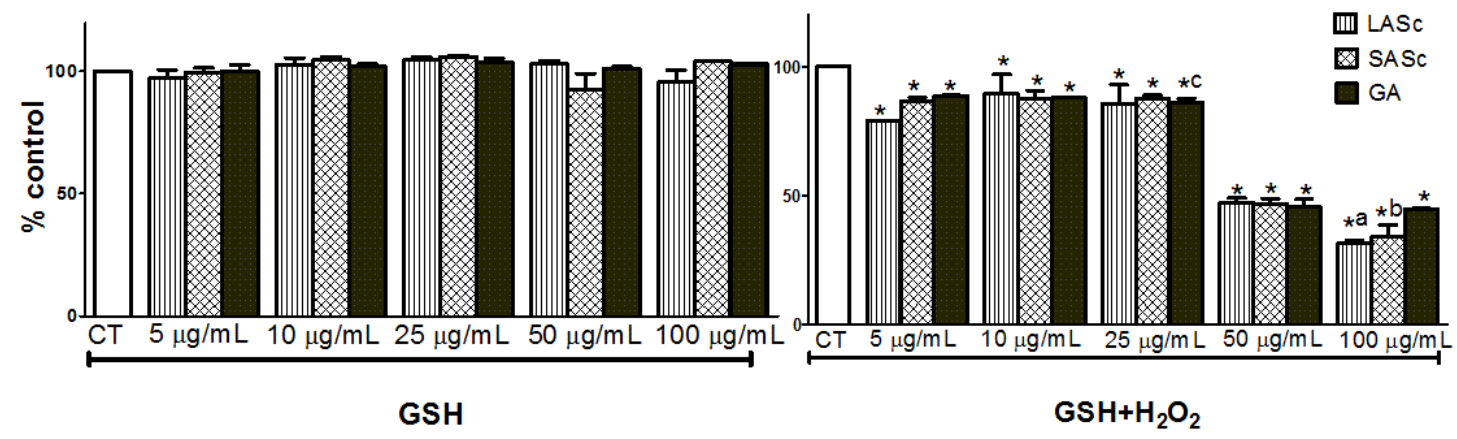

Fig2: (a) Thiol peroxidase-like activity of LASc, SASc and GA in the absence or (b) presence of $\mathrm{H}_{2} \mathrm{O}_{2}$.

.Each value is expressed as mean \pm SEM, $n=3$. Data were analyzed by one-way ANOVA followed by Duncan's multiple comparison post hoc test. denotes $\mathrm{p}<0.001$ when compared to controls (CT); ${ }^{a}$ denotes $\mathrm{p}<0.0001$ different from LASc 5, 10, 25 and $50 \mu \mathrm{g} / \mathrm{mL}$; ${ }^{\mathrm{b}}$ denotes p<0.0001 when compared to SASc 5,10,

25 and $50 \mu \mathrm{g} / \mathrm{mL}$ and $^{\mathrm{c}}$ denotes difference from GA 50 and $100 \mu \mathrm{g} / \mathrm{mL}$. LASc, aqueous leaves extract of S. cumini; SASc, aqueous seeds extract of S. cumini; GA, gallic acid.

\section{Nitric Oxide-Scavenging Assay}

The NO radical scavenging property of the extracts and GA is represented in the Fig.1d. The extracts had a similar scavenging ability in the most of the concentrations tested, except at the concentration $100 \mu \mathrm{g} / \mathrm{mL}$, where LASc exhibited higher $(\mathrm{p}<0.001)$ scavenging potential than SASc.

\section{Thiol Peroxidase-Like Activity}

Thiol peroxidase-like activities from both extracts and GA are shown in fig. 2a. None of the extracts were able to promote the consumption of $\mathrm{GSH}$ in the absence of $\mathrm{H}_{2} \mathrm{O}_{2}$ in the concentrations tested. However, we can observe a decrease in $\mathrm{SH}$ groups when LASc, SASc and GA were incubated in the presence of $\mathrm{H}_{2} \mathrm{O}$ at all concentrations tested (Fig. 2b).

\section{In vitro effect of LASc, SASc and GA in AAPH-induced} oxidative stress in the peripheral lymphocytes Enzymatic activities in the peripheral lymphocytes NTPDase, ADA activities assays

Fig. 3 and 4 shows that the in vitro effect of NTPDase on ATP (a) and ADP (b) hydrolysis and ADA activities after AAPH exposure in lymphocytes was significantly increased compared 
with the control $(\mathrm{p}<0.01)$. LASc and SASc at all concentrations tested prevented the increase in NTPDase activity (ADP and ATP substrates) induced by AAPH ( $\mathrm{p}<0.0001 ; \mathrm{p}<0.01 ; \mathrm{p}<0.0001)$. Similarly, results were found concerning ADA activity for both the extracts tested.

Otherwise, LASc and SASc $(500 \mu \mathrm{g} / \mathrm{mL})$, per se, reduced ATP and ADP hydrolysis compared to control $(\mathrm{p}<0.0001)$. The per se effect was also observed in relation to ADA activity (Fig. 4a) with LASc (100 and $500 \mu \mathrm{g} / \mathrm{mL}, \mathrm{p}<0.05)$, SASc $(50$ and $100 \mu \mathrm{g} / \mathrm{mL}, \mathrm{p}<0.0001 ; \mathrm{p}<0.05)$.

Furthermore, when only the lymphocytic suspension was incubated with EHNA $(100 \mu \mathrm{M})$ a markedly reduction of ADA1 activity in vitro was observed $(77,83 \%)$. This reveals that the isoform 1 is predominant in the tested lymphocytes, and therefore, this isoform is the main responsible for the enzymatic activity observed in all assays (Fig. 4b).

\section{AChE activity}

LASc (50 and $100 \mu \mathrm{g} / \mathrm{mL})$ and SASc $(50 \mu \mathrm{g} / \mathrm{mL})$ were able to prevent the strong inhibition of enzymatic activity promoted by AAPH $(\mathrm{p}<0.05)$. The seeds and leaves effects were different as shown in Fig. 5, according to the concentration analyzed. However, LASc at $500 \mu \mathrm{g} / \mathrm{mL}$ exhibited a synergistic effect with AAPH.
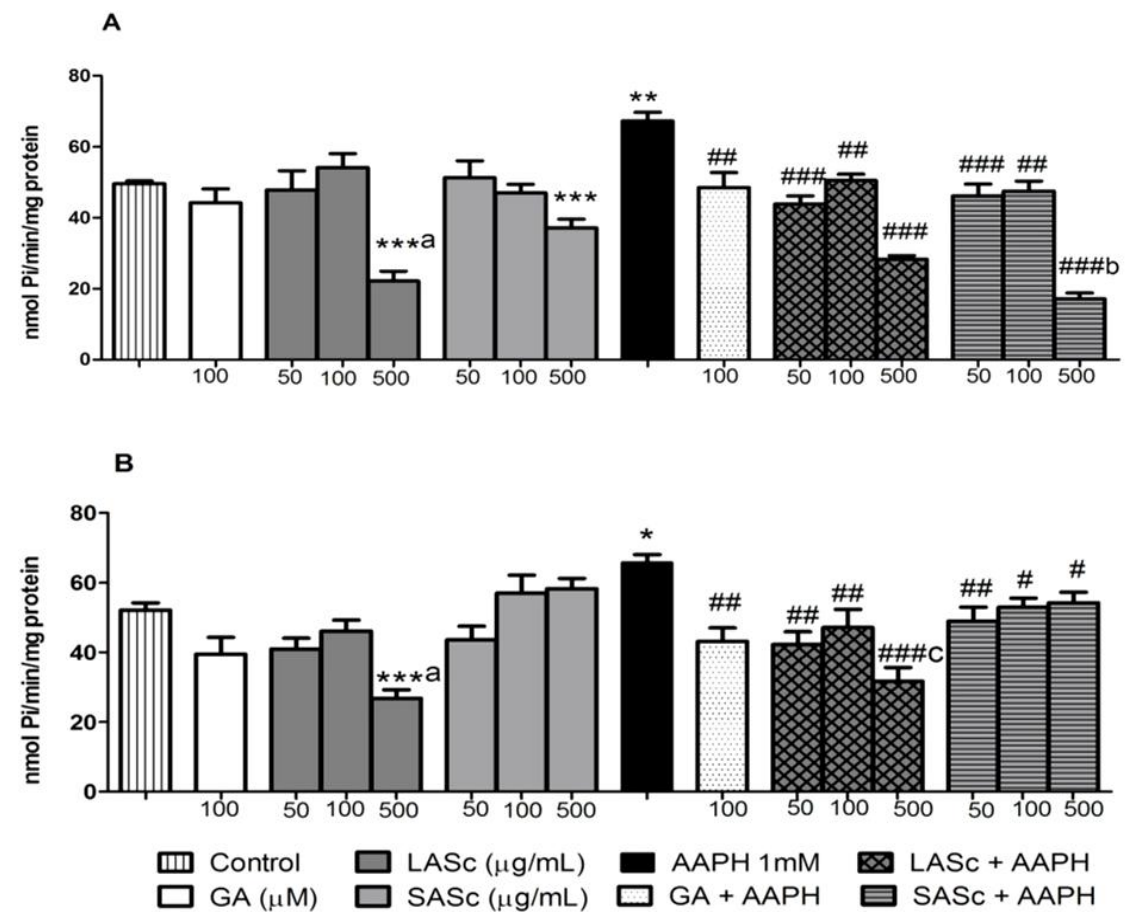

Fig. 3: Effect of GA, LASc and SASc in (a) ATP and (b) ADP hydrolysis in lymphocytes suspensions after $2 \mathrm{~h}$ of incubation with AAPH, in vitro. Data are reported as mean \pm S.E.M. $(n=8)$. Statistically significant differences were determined by one-way ANOVA followed by Duncan's multiple range test $(*$ $\mathrm{p}<0.05,{ }^{* *} \mathrm{p}<0.01$ and $* * * \mathrm{p}<0.0001$ indicates difference from control group; ${ }^{\#} \mathrm{p}<0.05,{ }^{\#} \mathrm{p}<0.01$ and ${ }^{\# \#} \mathrm{p}<0.0001$ compared to AAPH $1 \mathrm{mM} ;{ }^{\mathrm{a}} \mathrm{p}<0.0001$ compared to SASc $500 \mu \mathrm{g} / \mathrm{mL} ;{ }^{b} \mathrm{p}<0.05$ compared to LASc $500 \mu \mathrm{g} / \mathrm{mL}+\mathrm{AAPH} ;{ }^{\mathrm{p}} \mathrm{p}<0.01$ compared to SASc $500 \mu \mathrm{g} / \mathrm{mL}+\mathrm{AAPH}$.

A

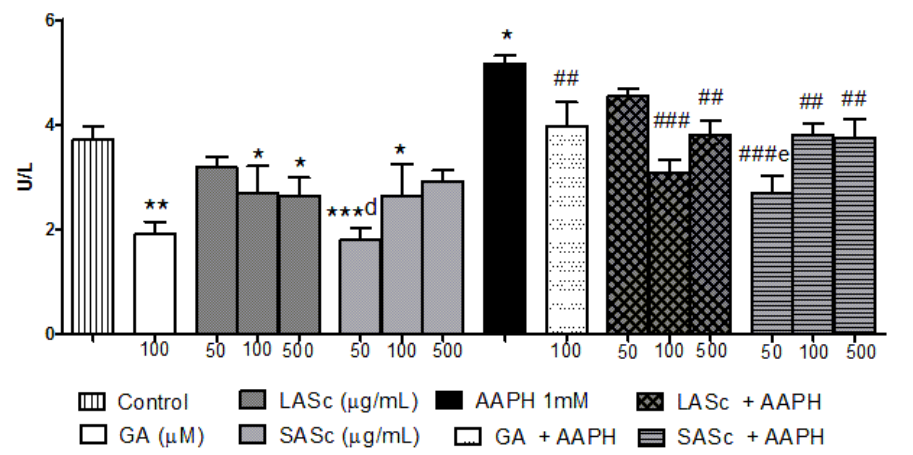

B

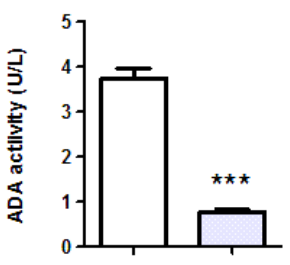

Control EHNA $100 \mu \mathrm{M}$

Fig. 4: Effect of GA, LASc and SASc in (a) ADA activities in lymphocytes suspensions after 2 h of incubation with AAPH, in vitro (b) Lymphocytes suspensions after incubation with EHNA. Data are reported as mean \pm S.E.M. $(n=8)$. Statistically significant differences were determined by one-way ANOVA followed by Duncan's multiple range test $\left(* \mathrm{p}<0.05,{ }^{* *} \mathrm{p}<0.01\right.$ and $* * * \mathrm{p}<0.0001$ indicates difference from control group; ${ }^{\# \#} \mathrm{p}<0.01$ and ${ }^{\# \#} \mathrm{p}<0.0001$ compared to AAPH $1 \mathrm{mM} ;{ }^{d} \mathrm{p}<0.0001$ compared to LASc $50 \mu \mathrm{g} / \mathrm{mL}$ and ${ }^{\mathrm{e}} \mathrm{p}<0.01$ compared to LASc $\left.50 \mu \mathrm{g} / \mathrm{mL}+\mathrm{AAPH}\right)$. 


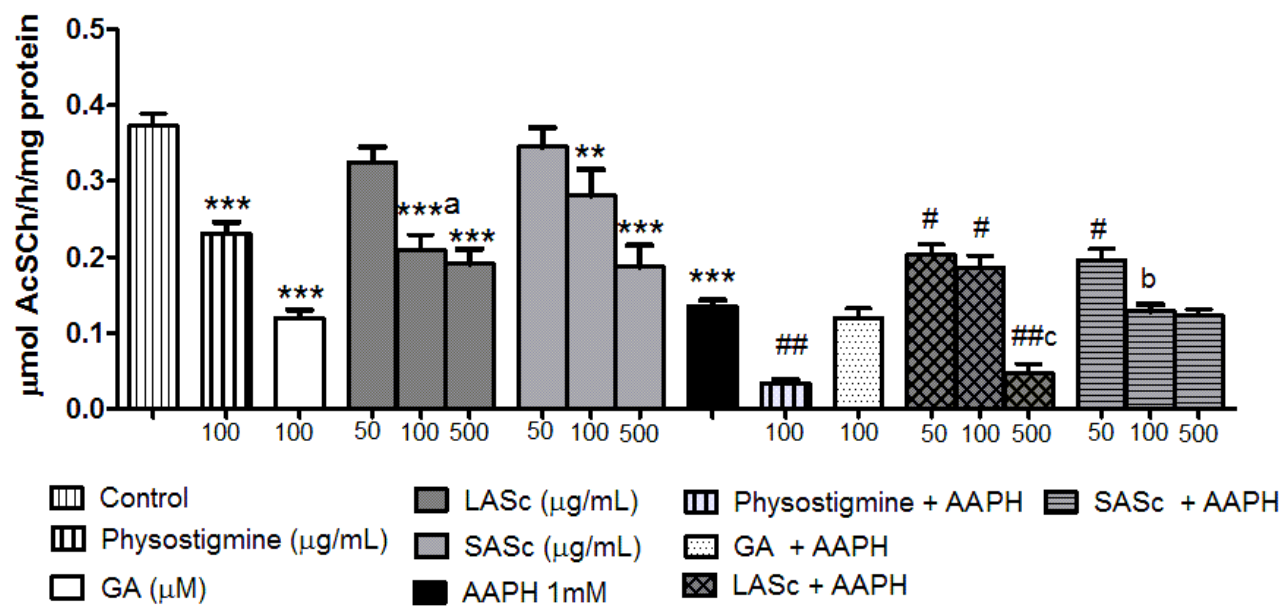

Fig.5: In vitro effect of GA, LASc and SASc on AChE activity in lymphocytes suspensions after $2 \mathrm{~h}$ of incubation with AAPH. Data are reported as mean \pm S.E.M. $(\mathrm{n}=8)$. Statistically significant differences were determined by one-way ANOVA followed by Duncan's multiple range test (** $\mathrm{p}<0.01$ and $* * * \mathrm{p}<0.0001$ compared to control group; ${ }^{*} \mathrm{p}<0.05,{ }^{\#} \mathrm{p}<0.01$ compared to AAPH $1 \mathrm{mM} ;{ }^{a} \mathrm{p}<0.01$ compared to SASc $100 \mu \mathrm{g} / \mathrm{mL} ;{ }^{\mathrm{b}} \mathrm{p}<0.05$ compared to LASc $100 \mu \mathrm{g} / \mathrm{mL}+\mathrm{AAPH} ;{ }^{\mathrm{c}} \mathrm{p}<0.01$ compared to SASc $500 \mu \mathrm{g} / \mathrm{mL}+\mathrm{AAPH}$.

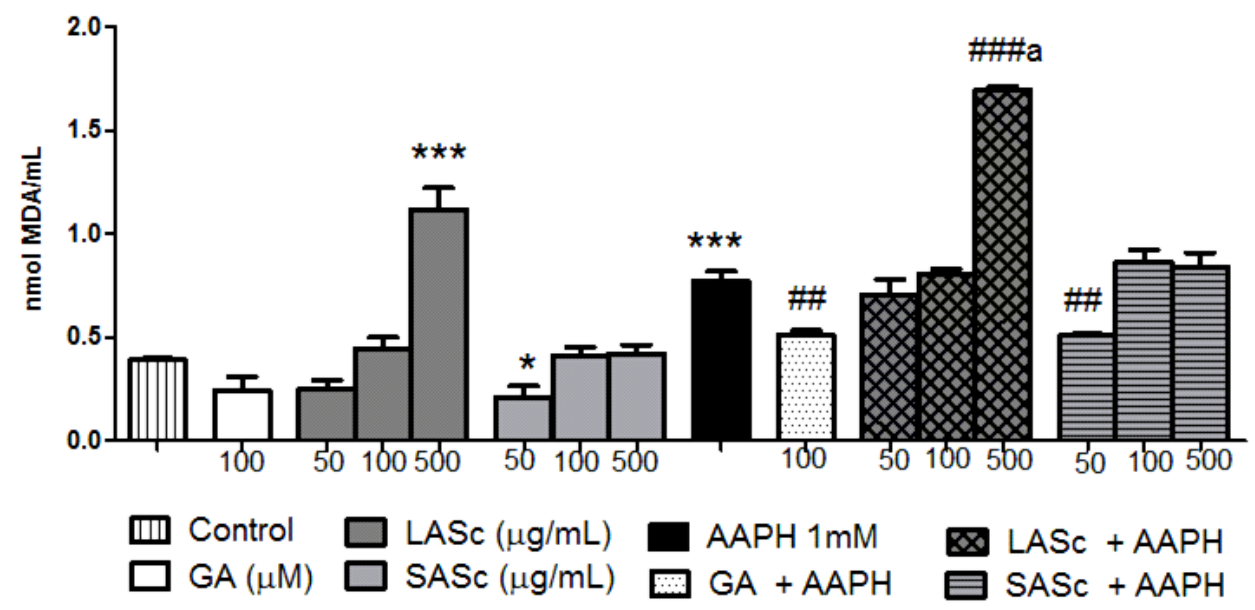

Fig. 6: In vitro effect of LASc, SASc and GA on TBARS levels in lymphocytes suspensions after $2 \mathrm{~h}$ of incubation with AAPH. Values are expressed as mean \pm SEM $(n=8)$. Statistically significant differences were determined by one-way ANOVA followed by Duncan's multiple range test $\left(* \mathrm{p}<0.05\right.$ and $* * * \mathrm{p}<0.0001$ compared to control group; ${ }^{\#} \mathrm{p}<0.01$ and ${ }^{\# \#} \mathrm{p}<0.0001$ compared to AAPH $1 \mathrm{mM} ;{ }^{\mathrm{a}} \mathrm{p}<0.0001$ compared to SASc $500 \mu \mathrm{g} / \mathrm{mL}+$ AAPH).

\section{Oxidative stress parameters}

TBARS levels

As shown in Fig. 6, the incubation of the lymphocytes in the presence of AAPH promoted a significant increase in lipoperoxidation levels compared with the control $(\mathrm{p}<0.0001)$. Only GA and the SASc at $50 \mu \mathrm{g} / \mathrm{mL}$ were able to protect the cells by reducing TBARS levels generated by AAPH $(\mathrm{p}<0.01)$. Unexpectedly, we observed that LASc $(500 \mu \mathrm{g} / \mathrm{mL})$ per se and in the presence of AAPH caused a lipoperoxidation increase $(\mathrm{p}<0.0001)$.

\section{P-SH groups}

As expected, a decrease in $\mathrm{P}-\mathrm{SH}$ groups was observed when the lymphocytes suspensions were incubated with AAPH $(\mathrm{p}<0.0001$, Fig. 7). LASc and SASc tested were able to protect the lymphocytes by increasing $\mathrm{P}-\mathrm{SH}$ groups levels in presence of
AAPH, wherein LASc had a greater ability than SASc at all concentrations tested (Fig. 6).

\section{NOx production}

The AAPH and aqueous extracts' effects on NOx production by lymphocytes are summarized in Fig. 8 and it reveals that the LASc (50 and $100 \mu \mathrm{g} / \mathrm{mL}$ ) and SASc at all concentrations tested protected the cells by decreasing NOx levels promoted by AAPH.

\section{Cell viability}

In vitro exposure of lymphocytic suspension to AAPH caused a marked reduction of cell viability $(41 \%)$ and LASc at all concentrations tested and SASc $(100$ and $500 \mu \mathrm{g} / \mathrm{mL})$ were able to protect cell viability. Besides, LASc revealed better effect than SASc at all concentrations (Table 1). 


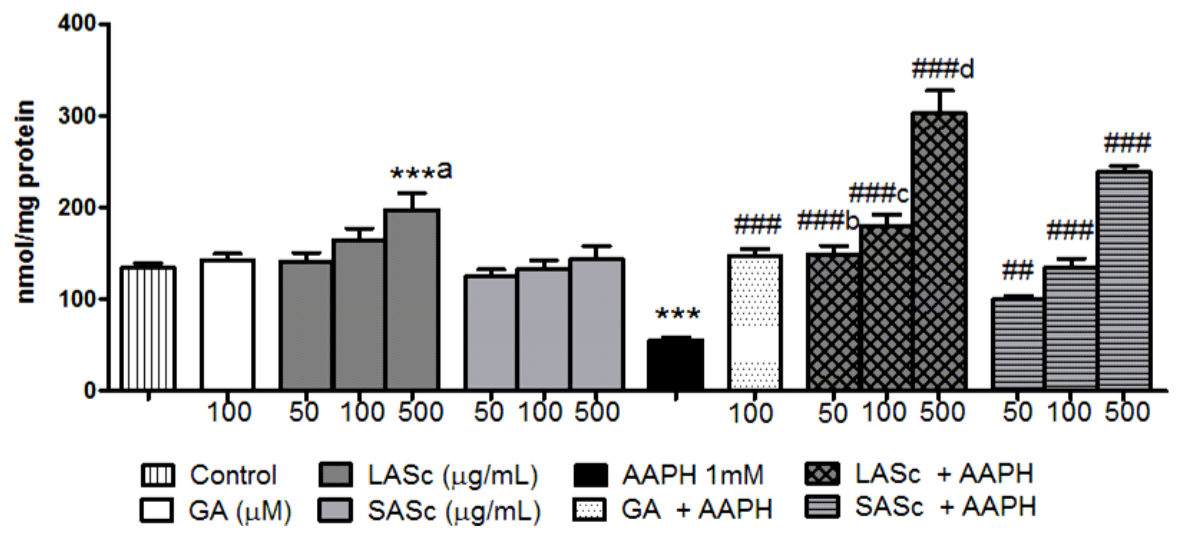

Fig. 7: In vitro effect of LASc, SASc and GA on P-SH levels in lymphocytes suspensions after $2 \mathrm{~h}$ of incubation with AAPH. Statistically significant differences were determined by one-way ANOVA followed by Duncan's multiple range test (*** $p<0.0001$ compared to control; ${ }^{*}$ $\mathrm{p}<0.01$ and ${ }^{\# \#} \mathrm{p}<0.0001$ compared AAPH $1 \mathrm{mM} ;{ }^{\mathrm{a}} \mathrm{p}<0.01$ compared to SASc $500 \mu \mathrm{g} / \mathrm{mL} ;{ }^{\mathrm{b}} \mathrm{p}<0.01$ compared to SASc $50+$ AAPH; ${ }^{\mathrm{c}} \mathrm{p}<0.05$ compared to SASc $100+\mathrm{AAPH} ;{ }^{\mathrm{d}} \mathrm{p}<0.0001$ compared to SASc 500+AAPH.

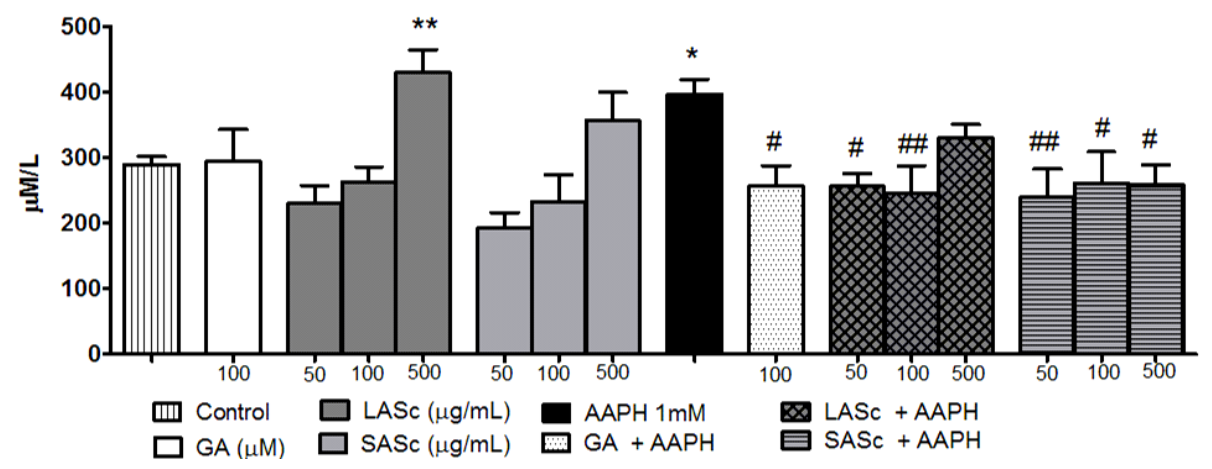

Fig. 8: In vitro effect of LASc, SASc and GA on NOx production in lymphocytes suspensions after $2 \mathrm{~h}$ of incubation with AAPH. Statistically significant differences were determined by one-way ANOVA followed by Duncan's multiple range test $\left(* \mathrm{p}<0.05 ; * * \mathrm{p}<0.01\right.$ compared to control; ${ }^{\#}$ $\mathrm{p}<0.05 ;{ }^{\#} \mathrm{p}<0.01$ compared to AAPH $1 \mathrm{mM}$.

Table 1: In vitro effect of LASc, SASc and GA on MTT assay in lymphocytes suspensions after $2 \mathrm{~h}$ of incubation with AAPH.

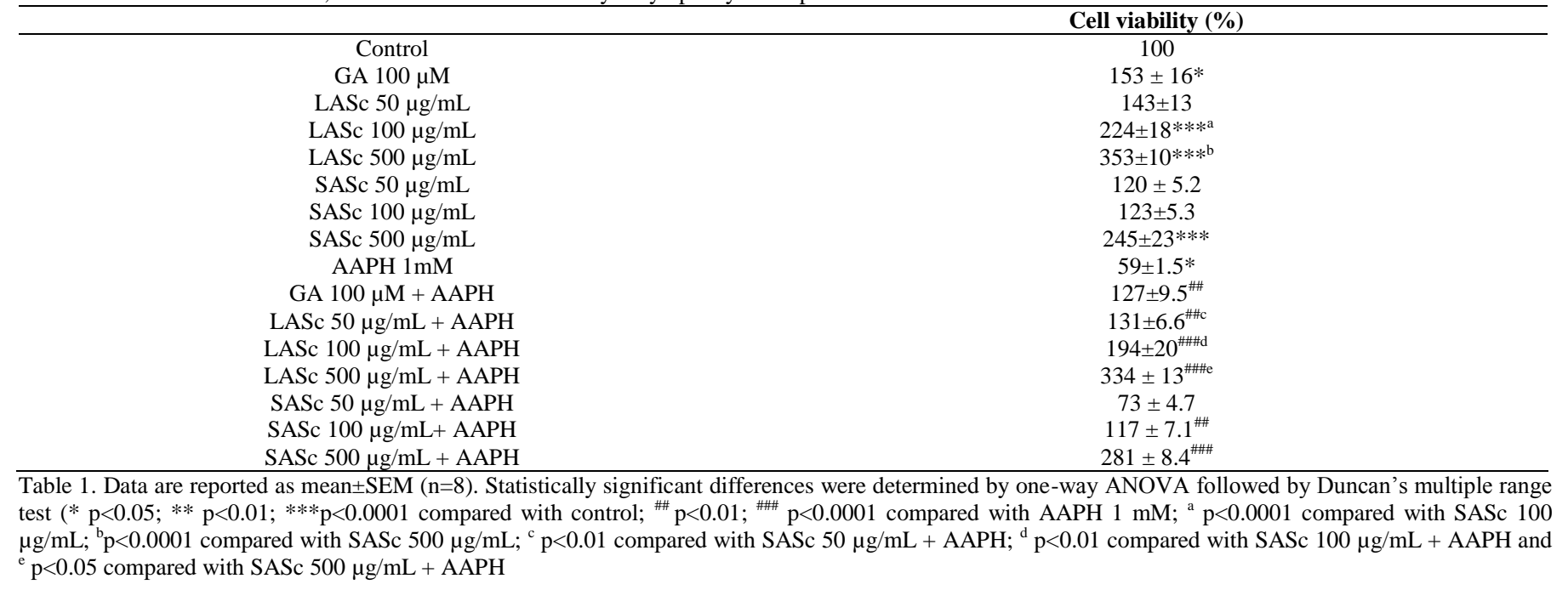

\section{DISCUSSION}

Different approaches have been developed to analyze anti-inflammatory and antioxidant activities of medicinal plants (Madhulika et al., 2016; Mireille, 2001). In the same manner, with the current and growing interest in oxidative damage mechanisms, azo compounds have frequently been used as convenient free radical initiators. The results of this study clearly indicate the high antioxidant activities and free radical scavenging effect of $S$. cumini extracts that are linked to their phytochemical composition 
marked by the presence of polyphenolic compounds that are known to have several pharmacological activities (Ushida et al., 2008).

The LASc, SASc and GA have potent antioxidant activity against in vitro oxidative systems, since they showed effectiveness as scavengers of DPPH, NO and $\mathrm{H}_{2} \mathrm{O}_{2}$, reductive ability $\mathrm{Fe}^{+3}$ to $\mathrm{Fe}^{+2}$, thiol peroxidase-like activity that mimic the properties of glutathione peroxidase (GPx). These in vitro assays indicate LASc and SASc as a significant source of natural antioxidant, possibly due to their ability to scavenge the free radicals and to reduce the intracellular ROS generation which might be helpful in preventing the oxidative stress progress.

Also, the exposure of lymphocytes to AAPH was capable of increasing the activities of the ADA and NTPDases, lipoperoxidation and NO production and reduces AChE activity, P-SH and MTT levels. These results can be assigned on the ability of the hydrophilic radical generator of this azo compound to generate peroxyl radicals, thereby oxidizing lymphocytic suspension (Frei and Gaziano, 1993). Likewise, concerning ectoenzymes, AAPH exposure causes a raise in lymphocytic NTPDases (hydrolyzing ATP and ADP), increasing the release of ATP from stressed cells to extracellular space during inflammation (Virgilio et al., 2009) and ADP may have been formed as consequence of inflammatory process (Bours et al., 2006). Sequentially, the increase in ADA activity could be attributed to an attempt of the organism to compensate the high levels of ATP released, which may affect adenosine levels available for adenosine receptors stimulation expressed on the T-cell surface, leading to impairment of immune regulation and inflammatory process (Mandapathil et al., 2010). Subsequently, the reduction in Ado levels contributes to release of pro-inflammatory cytokines and NO production (Haskó and Cronstein, 2004). Taking into account our results, they suggest that an increase of nucleotide hydrolysis and adenosine deamination in AAPH-induced can lead to inflammatory and immune alterations in lymphocytes. Moreover, it indicates that when ROS levels are generated in excess, cells redox homeostasis is disturbed affecting the redoxsensitive signal transduction cascades, leading to an unbalanced purinergic and immunologic systems and an immune cells activation (Smale, 2011). These immunobiochemical pathways may potentially be altered in the pathological state including infections, autoimmune syndromes, malignant disease, neurodegeneration and cardiovascular disorders (Schetinger et al., 2007; Becker et al., 2014).

Importantly in this study was that both LASc and SASc protected the lymphocytes against the NTPDase and ADA activities increase by preventing AAPH-induced toxicity that may result in an increase of ATP in order to enhance Ado levels production, which has anti-inflammatory effects. Thus, Ado becomes available to exert its anti-inflammatory function by activating receptors present on the cells surfaces, regulating the release of molecules involved in the immune system and also inhibiting the release of NO (Haskó and Cronstein, 2004). Another important aspect to be discussed here is the AAPH effect on the cholinergic system in lymphocytes. For the first time to our knowledge, this peroxyl radicals initiator was tested in lymphocytes AChE activity causing strong inhibition which affect the acetylcholine levels acting as a compensatory mechanism in order to attenuate the intensity of the progression of inflammatory processes since ACh exhibits the anti-inflammatory effect. Notwithstanding, the pretreatment with LASc $(100 \mu \mathrm{g} / \mathrm{mL})$ and SASc $(50 \mu \mathrm{g} / \mathrm{mL})$ prevented this strong inhibition reestablishing the AChE activity. This prevention would minimize the effects generated by exposure to the peroxyl radical initiator, thus, it would decrease the load on the AChE activity.

Although SASc $(50 \mu \mathrm{g} / \mathrm{mL})$ and GA have protected lymphocytes against lipoperoxidation, LASc was not able to do it, corroborating with previous study our group (De Bona et al., 2015). Nevertheless, LASc and SASc in all concentrations tested were able to protect levels of $\mathrm{P}-\mathrm{SH}$ groups indicating that antioxidants compound work against ROS in order to protect the sulfhydryl groups cells from the deleterious effects of oxidative stress (Pandey and Rizvi, 2011) favoring to the proper function of lymphocytes (Knight, 2000).

Furthermore, the pretreatment with LASc and SASc improved cell viability, a cytoprotective effect, and suggested its potential application against ROS-mediated cell damage (Veigas et al., 2008). In fact, AAPH easily penetrates the lymphocytes cellular membrane and accumulated inside these cells, changing the biomembrane composition, potentially leading to an interference with cell-signaling pathways and even to the loss of cell function and viability (Hu et al., 2005), as it can be observed in MTT assay.

We suggest that the differential protective effect exerted by LASc and SASc in some parameters can be linked to the bioactive molecules present in them, since phytochemical characterization previously published (Cargnelutti et al., 2015, Bitencourt et al., 2016) revealed that GA is present in high quantities in both extracts but, LASc exhibits also high concentration of quercetin and caffeic acid. In fact, quercetin has already been able to modulate AChE activity in rats' lymphocytes orally exposed to Cadmium (Abdalla et al., 2014) and an extract containing significant amounts of caffeic acid increased the viability of lymphocytes exposed to $\mathrm{H}_{2} \mathrm{O}_{2}$ (Sagrillo et al., 2015) also, caffeic acid contributed to the antioxidant defense system of HepG2 cells (Razali et al., 2015). Regarding SASc, which presented high concentrations of chlorogenic acid and rutin, it has recently been shown that the Scutia buxifolia Reissek extract with a similar composition was able to inhibite NTPDase in rats lymphocytes (Boligon et al., 2015) while rutin significantly reduced ADA activity in rats induced by carrageenan (ArrudaSilva et al., 2014). Moreover, chlorogenic acid brought TBARS levels in diabetic rats down to normal values (Stefanello et al., 2014). The basis for these distinct effects may be attributed to their structure-dependent physicochemical interactions with biologic membranes which would explain these differential results to the extracts (Böhm et al., 2012). The results of our study still deserve some considerations. When exposure per se and/or in the presence 
of AAPH, LASc $(500 \mu \mathrm{g} / \mathrm{mL})$ increased lipoperoxidation. In the same way, it had a synergistic effect with AAPH that led to strong inhibition of AChE activity. These effects may be attributed to the ability of the flavonoids to act as antioxidants/prooxidants under in vitro system to be dependent on a number of factors such as concentration, structure, the test system (Procházková et al., 2011) and also, it is thought to be directly proportional to the total number of hydroxyl groups (Cao et al., 1997). This suggests that a molecule with the same chemical structure may optimize antioxidant capacity and it can also exacerbate oxidative stress and damage the cellular molecules (Heim et al., 2002).

\section{CONCLUSION}

In conclusion, the results of the present investigation indicate that the exposure to AAPH caused changes in the purinergic and cholinergic system's enzymes, as well in parameters of oxidative stress that possibly contributes to decrease viability cellular and to the inflammation process in lymphocytes. Mainly, the ADA1 was affected in the model tested. Of particular importance, our findings indicated that the $S$. cumini's leaves and seeds extract were able to generate significant effects, preventing these changes across modulation of the ectonucleotidases activities, probably preserving the ATP and Ado levels, which could lead to an anti-inflammatory status. Besides, the extracts can regulate the AChE activity leading to immune system control carried out by the lymphocytes. Such effects may be a consequence of the compounds in higher concentration present in the medicinal extract preparations investigated.

\section{ACKNOWLEDGMENT}

Financial support and sponsorship: The authors wish to thank the Conselho Nacional de Desenvolvimento Científico e Tecnológico (CNPq-Pq303245/2014-0). The first author acknowledges the fellowship from the Coordenação de Aperfeiçoamento de Pessoal de Nível Superior (CAPES).

Conflict of Interests: There are no conflicts of interest.

\section{REFERENCES}

Abdalla, FH, Cardoso AM, Schmatz R, Gonçalves JF, Baldissarelli J, Martins CC, Zanini D, De Oliveira LS, Da Costa P, Pimentel VC, Pereira LB, Lhamas CL, Schetinger MR, Morsch VM, Mazzanti CM. Protective effect of quercetin in ecto-enzymes, cholinesterases, and myeloperoxidase activities in the lymphocytes of rats exposed to cadmium. Mol Cell Biochem, 2014; 396: 201-211.

Ali Hassan SH, Fry JR, Abu Bakar MF. Phytochemicals content, antioxidant activity and acetylcholinesterase inhibition properties of indigenous garcinia parvifolia fruit, Biomed Res Int, 2013; 31:138950.

Arruda-Silva F, Nascimento MV, Luz AB, Venzke D, Queiroz GS, Fröde TS, Pizzolatti MG, Dalmarco EM.. Polygala molluginifolia A. St.-Hil. and Moq. prevent inflammation in the mouse pleurisy model by inhibiting NF- $\mathrm{BB}$ activation. Int Immunopharmacol, 2014; 19(2): 334-341.

Ayyanar M, Subash-Babu P, Ignacimuthu S. Syzygium cumini (L.) Skeels., a novel therapeutic agent for diabetes: folk medicinal and pharmacological evidences. Complement. Ther Med, 2013; 21: 232-43.
Bajpai, M., Pande A, Tewari SK, and Prakash D. Phenolic contents and antioxidant activity of some food and medicinal plants. Int $\mathbf{J}$ Food Sci Nutr, 2005; 56: 287-291.

Becker K, Schroecksnadel S, Gostner J, Zaknun C, Schennach $\mathrm{H}$, Überall F, Fuch D. Comparison of in vitro tests for antioxidant and immunomodulatory capacities of compounds. Phytomedicine 2014; 2: $164-171$.

Benzie IF, Strain JJ. 1996. The ferric reducing ability of plasma (FRAP) as a measure of "antioxidant power": the FRAP assay. Anal. Biochem, 1996; 239: 70-76.

Bitencourt PER, Ferreira LM, Cargnelutti LO, Denardi L, Boligon A, Fleck M, Brandão R, Atahyde ML, Cruz L, Zanette RA, Alvez $\mathrm{SH}$, Moretto MB. A new biodegradable polymeric nanoparticle formulation containing Syzygium cumini: Phytochemical profile, antioxidant and antifungal activity and in vivo toxicity. Ind Crops Prod, 2016; 83: 400-407.

Bitencourt PER, De Bona K, Cargnelutti L, Bonfanti G, Pigatto A, Boligon A, Athayde ML, Pierezan F, Zanette RA, Moretto MB. Syzygium cumini seed extract ameliorates adenosine deaminase activity and biochemical parameters but does not alter insulin sensitivity and pancreas architecture in a short-termmodel of diabetes. J Complem Integr Med, 2015; 12: 1-7.

Böhm F, Edge R, Truscott G. Interactions of dietary carotenoids with activated (singlet) oxygen and free radicals: Potential effects for human health. Mol Nutr Food Res, 2012; 56: 205-216.

Boligon AA, Pimentel VC, Bagatini MD, Athayde ML. Effect of Scutia buxifolia Reissek in nucleotidase activities and inhibition of platelet aggregation. J Nat Med, 2015; 69: 46-54.

Borges A, Ferreira C, Saavedra MJ, Simões M. Antibacterial Activity and Mode of Action of Ferulic and Gallic Acids Against Pathogenic Bacteria. Microb Drug Resist, 2013; 19(4): 256-265.

Bours, MJ, Swennen EL, Di Virgilio F, Cronstein BN, Dagnelie PC. Adenosine 5-triphosphate and adenosine as endogenous signaling molecules in immunity and inflammation. Pharmacol Ther, 2006; 112: $358-404$

Boyne, AF, Ellman GL.. A methodology for analysis of tissue sulfhydryl components. Anal Biochem, 1972; 46:639-65.

Böyum A. Isolation of mononuclear cells and granulocytes from human blood. Isolation of mononuclear cells by one centrifugation and of granulocytes by combining centrifugation and sedimentation at $1 \mathrm{~g}$. Scand J Clin Lab Invest Suppl, 1968; 97: 77-89.

Brigelius-Flohe R, Flohe L. Basic principles and emerging concepts in the redox control of transcription factors. Antioxid Redox Signal, 2011; 15: 2335-2381.

Burch LH, Picher M. E-NTPDases in human airways: regulation and relevance for chronic lung diseases. Purinergic Signal 2006; 2: 399-408.

Cao G, Sofic E, Prior RL. Antioxidant and prooxidant behavior of flavonoids: structure-activity relationships. Free Radic Biol Med, 1997; 22: $749-760$.

Cargnelutti LO, Bitencourt PER, Bochi G, Duarte T, Boligon A, Pigatto AS, Athayde ML, Moresco RN, Moretto MB. Syzygium cumini Leaf Extract Protects Against Ethanol Induced Acute Injury in Rats by Inhibiting Adenosine Deaminase Activity and Proinflammatory Cytokine Production. Res J Phytochem, 2015; 9: 56-67.

Chan KM, Delfert D, Junger KD. A direct colorimetric assay for Ca+2- stimulated ATPase activity. Anal Biochem, 1986; 157: 375-380. Cope AP. Studies of T-cell activation in chronic inflammation. Arthritis Res Ther, 2002; 4:197-211.

De Bona KS, Bonfanti G, Bitencourt PER, Borges RM, Boligon, A, Pigatto A, Athayde ML, Moretto MB. Protective effect of gallic acid and Syzygium cumini extract against oxidative stress-induced cellular injury in human lymphocytes. Drug Chem Toxicol, 2016; 39(3): 256-263.

De Bona KS, Bonfanti G, Bitencourt PE, Cargnelutti LO, Da Silva PS, Da Silva TP, Zanette RA, Pigatto AS, Moretto MB. Syzygium cumini is more effective in preventing the increase of erythrocytic ADA activity than phenolic compounds under hyperglycemic conditions in vitro. J Physiol Biochem, 2014; 70(2): 321-330. 
Delves P, Martin S, Burton D, Roitt I. Roitt's essential immunology, 2006; 11th ed. Hoboken (NJ): Wiley-Blackwell.

Di Virgilio, F, Ceruti S, Bramanti P, Abbracchio MP. Purinergic signalling in inflammation of the central nervous system. Trends Neurosci 2009, 32: 79-87.

Eidi A, Eidi M, Esmaeili E. Antidiabetic effect of garlic (Allium sativum L.) in normal and streptozotocin-induced diabetic rats. Phytomedicine, 2006; 13: 624-629.

Ellman GL, Courtney DK, Andres V, Feather-Stone RM. A new and rapid colorimetric determination of acetylcholinesterase activity. Biochem Pharmacol, 1961; 7: 88-95.

Ellman GL. Tissue sulfhydryl groups. Arch. Biochem. Biophys, 1959; 82(1): 70-77.

Frei, B., Gaziano JM. Content of antioxidants, preformed lipid hydroperoxides, and cholesterol as predictors of the susceptibility of human LDL to metal ion-dependent and independent oxidation. J Lipid Res, 1993; 34: 2135-2145.

Gabrovska K, Marinov I, Godjevargova T, Portaccio M, Lepore M, Grano V, Diano N, Mita DG.. The influence of the support nature on the kinetics parameters, inhibition constants and reactivation of immobilized acetylcholinesterase. Int. J. Biol. Macromol, 2008; 43: 339345

Gessi S, Varani K, Merighi S, Fogli E, Sacchetto V, Benini A, Leung E, Mac-Lennan S, Borea PA. Adenosine and lymphocyte regulation. Purinergic Signal, 2007.3: 109-116.

Giusti G, Galanti B, 1984. Colorimetric method. In: Bergmeyer HU, editor. Methods of enzymatic analysis. Weinheim: Verlag Chemie, $315-23$.

Hasko G, Cronstein BN. Adenosine: An endogenous regulator of innate immunity. Trends Immunol, 2004; 25: 33-39.

Heim KE, Tagliaferro AR, Bobilya DJ.. Flavonoid antioxidants: chemistry, metabolism and structure-activity relationships. The J Nutr Biochem, 2002; 13(10): 572-584.

Hu C, Kwok BHL, Kitts DD. Saskatoon berries (Amelanchier alnifolia Nutt.) scavenge free radicals and inhibit intracellular oxidation, Food Res, 2005; 38: 1075-1085.

Jacques-Silva, MC, Nogueira CW, Broch LC, Flores EM, Rocha JB. Diphenyl disselenides and ascorbic acid changes deposition of selenium and brain of mice. Pharmacol Toxicol, 2001; 88:119-125.

Joshi R, Poonam Gulati A. Biochemical attributes of tea flowers (Camellia sinensis) at different developmental stages in the Kangra region of India. Sci.Hortic, 2011; 130, 66-74.

Kawashima K, Fujii T. The lymphocytic cholinergic system and its contribution to the regulation of immune activity. Life Sci, 2003; 74: 675-696.

Kim, KN, Heo SJ, Yoon WJ, Kang SM, Ahn G, Yi TH Fucoxanthin inhibits the inflammatory response by suppressing the activation of NF-kappa B and MAPKs in lipopolysaccharide-induced RAW 264.7 macrophages. Eur J Pharmacol, 2010; 649: 369-75.

Kim, SH, Jun CD, Suk K , Choi BJ, Lim H, Park S, Lee SH, Shin HY, Kim DK, and Shin T. Gallic acid inhibits histamine release and pro-inflammatory cytokine production in mast cells. Toxicol Sci, 2006; 91:123-131.

Knight JA. Review: free radicals, antioxidants, and the immune system. Ann Clin Lab Sci, 2000; 30:145-158.

Langston, HP, Ke Y, Gewirtz AT, Dombrowski KE, Kapp JA. Secretion of IL-2 and IFN-, but not IL-4, by antigen-specific T cells requires extracellular ATP. J Immunol, 2003; 170: 2962-70.

Leal DB, Streher CA, Neu TN, Bittencourt FP, Leal CA, Silva JEP, Morsch VM, Schetinger MRC. Characterization of NTPDase (NTPDase 1; ecto-apyrase; ecto-diphosphohydrolase; CD39; EC 3.6.1.5) activity in human lymphocytes. Biochim Biophys Acta, 2005; 1721: 9-15.

Lowry OH, Rosebrough NJ, Farr AL, Randall RJ. Protein measurement with the folin phenol reagent. J Biol Chem, 1951; 193: 26575.

Madhulika Pradhan et al. Phytochemistry, Pharmacology and Novel Delivery Applications of Syzygium cumini (L.). Ijppr.Human, 2016; 7(1): 659-675.
Mandapathil M, Hilldorfer B, Szczepanski MJ, Czystowska M, Szajnik M, Ren J, Lang S, Jackson EK, Gorelik E, Whiteside TL. Generation and accumulation of immunosuppressive adenosine by human CD4+CD25highFOXP3+ regulatory T cells. J Biol Chem, 2010; 285: 7176-7186.

Mireille C. Le guide du préparateur en pharmacie d'Afrique noire. In. Edited by Ngcom, 2001; E. Paris 68.

Moretto, MB, Thomazi AP, Godinho G, Roessler TM, Nogueira CW, Souza DO, Wofchuk S, Rocha JB. Ebselen and diorganylchalcogenides decrease in vitro glutamate uptake by RAT brain slices: prevention by DTT and GSH. Toxicol In vitro, 2007; 21: 639-645.

Ohkawa H, Oshishi N, Yagi K. Assay of lipid peroxides in animal tissues by thiobarbituric acid reaction. Anal Biochem, 1979; 95: 351-358.

Padma VV, Sowmya P, Arun Felix T. Protective effect of gallic acid against lindane induced toxicity in experimental rats. Food chem toxicol, 2011; 49: 991-998.

Pandey, KB, Rizvi SI. Biomarkers of oxidative stress in red blood cells. Biomed Pap Med Fac Univ Palacky Olomouc Czech Repub, 2011; 155 (2): 131-6.

Perez de Castro I, Bivona TG, Philips MR, Pellicer A. Ras activation in Jurkat $\mathrm{T}$ cells following low-grade stimulation of the T-cell receptor is specific to N-Ras and occurs only on the Golgi apparatus. Mol Cell Biol, 2004; 24: 3485-3496.

Prince PS, Menon VP, Pari L.. Hypoglycaemic activity of Syzygium cumini seeds: effect on lipid peroxidation in alloxan diabetic rats. J Ethnopharmacol, 1998; 61: 1-7.

Procházková D, Boušová I, Wilhelmová N. Antioxidant and prooxidant properties of flavonoids. Fitoterapia, 2011; 82(4): 513-523.

Ravi K, Ramachandran B, Subramanian S. Protective effect of Eugenia jambolana seed kernel on tissue antioxidants in streptozotocin induced diabetic rats. Biol Pharm Bull, 2004; 27: 1212-1217.

Ravi, K., Ramachandran B, Subramanian S. Effect of Eugenia jambolana seed kernel on antioxidant defense system in streptozotocin induced diabetes in rats. Life Sci, 2004; 75: 2717-2731.

Ray PD, Huang BW, Tsuji Y. Reactive oxygen species (ROS) homeostasis and redox regulation in cellular signaling. Cell Signal, 2012; 24: $981-990$.

Razali N, Mat Junit S, Ariffin A, Ramli NS, Aziz AA. Polyphenols from the extract and fraction of $\mathrm{T}$. indica seeds protected HepG2 cells against oxidative stress. BMC Complement and Altern Medi, 2015; 18: 15:438.

Roberts RA, Smith RA, Safe S, Szabo C, Tjalkens RB, Robertson FM. Toxicological and pathophysiological roles of reactive oxygen and nitrogen species. Toxicol, 2010; 276:85-94.

Rock KL, Hearn A, Chen CJ, and Shi Y. Natural endogenous adjuvants. Springer Semin Immunopathology, 2005; 26: 231-246.

Ruch, RJ, Cheng SJ, Klaunig JE. Prevention of cytotoxicity and inhibition of intracellular communication by antioxidant catechins isolated from Chinese green tea. Carcinogenesis, 1989; 10: 1003-1008.

Sagrillo MR, Garcia LFM, Souza Filho OC, Duarte MMMF, Ribeiro EE, Cadona FC, Cruz IBM. Tucumã fruit extracts (Astrocaryum aculeatum Meyer) decrease cytotoxic effects of hydrogen peroxide on human lymphocytes. Food Chem, 2015; 173: 741-748.

Schetinger, MR, Morsch VM, Bonan CD, Wyse AT. NTPDase and 5-nucleotidase activities in physiological and disease conditions: New perspectives for human health. BioFactors, 2007.31(2): 77-98.

Smale ST. Hierarchies of NF-B target-gene regulation. Nat. Immunol, 2011; 12: 689-694.

Souza, ACG, Luchese C, Santos Neto JS, Nogueira CW. Antioxidant effect of a novel class of telluroacetilene compounds: Studies in vitro and in vivo. Life Sci, 2009; 84: 351-357.

Spychala, J. Tumor-promoting functions of adenosine. Pharmacol Ther, 2000; 87: 161-173.

Sreejayan N, Rao MNA.Nitric oxide scavenging by curcuminoids. J. Pharm. Pharmacol, 1997; 49: 105-107.

Stefanello N, Schmatz R, Pereira LB, Rubin MA, Da Rocha JB, Facco G, Pereira ME, Mazzanti CM, Passamonti S, Rodrigues MV, Carvalho FB, Da Rosa MM, Gutierres JM, Cardoso AM, Morsch VM, 
Schetinger MR. Effects of chlorogenic acid, caffeine, and coffee on behavioral and biochemical parameters of diabetic rats. Mol Cell Biochem, 2014; 388: 277-286.

Tatsch E, Bochi GV, Pereira RS, Kober H, Agertt VA, De Campos MM, Gomes P, Duarte MM, and Moresco RN. A simple and inexpensive automated technique for measurement of serum nitrite/nitrate. Clin Biochem, 2011; 44: 348-350.

Tayebati SK, El-Assouad D, Ricci A, Amenta F. Immunological and immunocytochemical characterization of cholinergic markers in human peripheral blood lymphocytes. J Neuroimmunol, 2002; 132:147155 .

Ungerer JP, Oosthuizen HM, Bissbort SH, Vermaak WJ. Serum adenosine deaminase: isoenzymes and diagnostic application. Clin Chem, 1992; 38: 1322-1326.

Ushida Y, T. Matsui M, Tanaka K, Matsumoto H. Hosoyama A, Mitomi Y, Sagesaka Y, Kakuda T. Endothelium-dependent vasorelaxation effect of rutin-free tartary buckwheat extract in isolated rat thoracic aorta. J Nutr Biochem, 2008; 19: 700-707.

Veigas JM, Shrivasthava R, Neelwarne B. Efficient amelioration of carbon tetrachloride induced toxicity in isolated rat hepatocytes by Syzygium cumini Skeels extract. Toxicol In Vitro, 2008; 22:1440-1446.

Vizzotto M C, Pereira M C. Caracterização das propriedades funcionais do jambolão. Embrapa Clima Temperado. Boletim de Pesquisa e Desenvolvimento, 2008; 79: 1-26.

\section{How to cite this article:}

Borges RM, Bitencourt PER, Stein CS, Bochi GV, Boligon AA, Moresco RN, Moretto MB. Leaves and seeds of Syzygium cumini extracts produce significant attenuation of 2,2 azobis-2amidinopropane dihydrochloride-induced toxicity via modulation of ectoenzymes and antioxidant activities. J App Pharm Sci, 2017; 7 (06): 037-048. 